'Departmant of General Surgery, Samsun Training and Research Hospital, Samsun, Turkey Departmant of Hematology Samsun Training and Research Hospital, Samsun, Turkey

Cite this article as: Sarı AC, Ocak S, Bük ÖF,

Büyükkaya P. Superior Mesenteric and Splenic Vein Thromboembolism due to PAI-1 SERPINE 4, MTHFR 1298 CC and Factor II Prothrombin 2021GA Mutations: A Case Report. Bosphorus Med J 2019;6(3):105-107.

Received: 19.08 .2019 Accepted: 23.09.2019

Correspondence: Dr. Sönmez Ocak. Samsun Eğitim ve Araştırma Hastanesi, Genel Cerrahi Anabilim Dalı, Samsun, Turkey Phone: $+905065314829$

e-mail: sonmezdr@gmail.com

\section{Superior Mesenteric and Splenic Vein Thromboembolism due to PAI-1 SERPINE 4, MTHFR 1298 CC and Factor II Prothrombin 2021GA Mutations: A Case Report}

\author{
PAI-1 SERPINE 4, MTHFR 1298 CC ve Faktör II \\ Prothrombin 2021GA Mutasyonlarına Bağlı \\ Superior Mezenterik Ven ve Splenik Ven \\ Trombozu: Olgu Sunumu
}

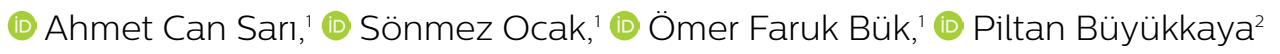

\begin{abstract}
Venous thromboembolism is known as a geriatric disorder, but sometimes, it can be seen in young adults. In these cases, the physician must consider genetic disorders for etiological factors, and genetic screening must be a part of the management plan. A previously healthy 34 years old man admitted to the emergency room with abdominal pain. After clinical and imaging evolution, a diagnosis of splenic infarct was made. After an uneventful splenectomy, the patient was re-admitted with severe abdominal pain and re-operated because of mesenteric ischemia. The genetic screening revealed PAI SERPINE 1 homozygous 4G/4G, MTHFR homozygous 1298 CC and factor II prothrombin 20210GA heterozygous mutations.
\end{abstract}

Keywords: Factor II prothrombin 20210GA; MTHFR 1298 CC; mutation; PAI SERPINE 14G/4G; polymorphism; venous thromboembolism.

\section{ÖZET}

Venöz tromboembolizm genellikle ileri yaşlarda görülmekle birlikte genç popülasyonda da görülebilmektedir. Bu olgularda etiyolojide genetik bozukluklar ön planda olduğundan genetik tarama tedavinin bir parçası olmalıdır. Otuz dört yaşında genç hasta karın ağrısı ile acil servise başvurdu. Klinik ve radyolojik bulgular dalak infarktını işaret etmişti. Sorunsuz bir splenektomiden sonra hasta ciddi karın ağrısı nedeniyle tekrar acile başvurdu ve mezenter iskemi tanısı ile tekrar opere edildi. Genetik tarama sonucunda hastada PAI SERPINE 1 homozigot 4G/4G, MTHFR homozigot 1298 CC and factor II prothrombin 20210GA heterozigot mutasyonlar saptandı.

Anahtar sözcükler: Faktör II Protrombin 20210 GA; MTHFR 1298 CC; mutasyon; PAI SERPINE 14G/4G; polimorfizm; venöz tromboembolizm.

M

esenteric venous thromboembolism (MVTE) constitutes approximately 5-15\% of the mesenteric ischemia, and early diagnosis is not possible in most patients. ${ }^{[1]}$ MVTE is classified as primary (idiopathic) or secondary MVTE. Due to the development of diagnostic methods, etiological factors can be detected in about $75 \%$ of the cases. Congenital or acquired coagulation disorders, cancer, intraabdominal infections, use of oral contraceptive and cirrhosis are the main etiological factors of the disease. ${ }^{[2]}$ 
In this case report, we present a young Turkish man with mesenteric ischemia and splenic infarct whom Factor IIProthrombin 20210 GA, methylenetetrahydrofolate reductase (MTHFR)1298CC and PAI SERPINE 1 4G/4G mutations were detected in postoperative genetic screening and the literature was reviewed.

\section{Case Report}

Thirty-four years old man admitted to emergency service with a pain in the left upper quadrant pain. His pain was lasted for a month, but it had worsened in the last two days. The patient did not have a significant medical history. His vital signs were as follows: blood pressure was 100/60 mmHg and pulse rate was 102 per minute. Abdomen physical examination revealed epigastric and left upper quadrant tenderness and rebound. In the laboratory studies, hemoglobin (Hb) level was $10.6 \mathrm{~g} / \mathrm{dL}$ and white blood cell count was 9800/uL. Contrast-enhanced abdomen tomography scan showed subscapular infarct areas at the mid-lateral zone of the spleen and free fluid density (compatible with blood) around the spleen. Also, superior mesenteric vein diameter was increased remarkably; peritoneal dirtiness and free fluid at the upper and mid quadrant of the abdomen were detected. These signs suggested mesenteric venous ischemia. Because of peritoneal irritation signs, suspicious of mesenteric venous ischemia and also splenic rupture due to splenic infarct laparotomy decision was made.

Perisplenic $200 \mathrm{~mL}$ defibrinated blood and serous peritoneal fluid were seen in the peritoneal cavity. Also, venous congestion was detected in proximal jejunal segments, but there were no signs of ischemia. Splenectomy was performed due to rupture and infarct. The postoperative period was uneventful, and the patient was discharged on the $2^{\text {nd }}$ postoperative day. One week after the surgery, the patient was re-admitted to the emergency room with severe abdominal pain, nausea and vomiting. He was fine without any complaint until the sixth postoperative day. His vital signs were unstable (blood pressure was $80 / 60 \mathrm{mmHg}$, pulse rate was 110 per minute). Abdominal examination revealed tenderness, defense and rebound in the right lower quadrant. In the laboratory studies, WBC: 34000/uL, Hb: $11.1 \mathrm{~g} / \mathrm{dL}$ and biochemical parameters were within normal ranges. Thrombi were detected in SMV, portal vein and proximal part of the splenic vein in contrast-enhanced abdominal tomography scan. Also, bowel ischemia signs in the right lower quadrant and extensive peritoneal free fluid were detected. The patient was taken to the operating room immediately for urgent laparotomy. During laparotomy, segmental bowel necrosis was seen in about 60 $\mathrm{cm}$ segment of proximal ileum. Segmental small bowel resection was performed, and intestinal continuity was obtained by a side-to-side isoperistaltic anastomosis. A ten-millimeter laparoscopic trocar was replaced at the bottom of the midline incision for second-look surgery after 24-hour diagnostic laparoscopy was performed. There were no signs of ischemia or necrosis in the rest of the bowels. Low molecular weight heparin (LMWH) enoxaparin sodium was administered $1 \mathrm{mg} /$ $\mathrm{kg}$ subcutaneously. On the postoperative second day, the patient suffered from fever and dyspnea. Atelectasis was detected at a chest X-ray. Respiratory exercise and oxygen support were given. Oral warfarin treatment at a dose of $5 \mathrm{mg} /$ day had started. Wound infection developed, and wound debridement was performed twice daily, and appropriate antibiotic treatment was administered by the wound culture result. LMWH was stopped when the INR level reached above 2 , and the patient was discharged on postoperative $16^{\text {th }}$ day. In his outpatient visit, blood samples taken for genetic tests to investigate hereditary thrombophilia. As a result of genetic screening, PAI SERPINE 1 homozygous 4G/4G, MTHFR homozygous 1298 CC and Factor II prothrombin 20210GA heterozygous were detected. MTHFR C667T, Factor 13 V34L and Factor V Leiden analysis were normal. The patient consulted the Department of Hematology and the continuation of anticoagulant treatment was recommended.

\section{Discussion}

Although numerous congenital and acquired factors are causing venous thromboembolism (VTE), genetic factors are coming to the foreground, particularly at the patients fifty years old. ${ }^{[3]}$ The gain of function mutations, such as Factor $\mathrm{V}$ Leiden mutation and prothrombin mutation, as well as the loss of function mutations, including Protein C, Protein S and anti-thrombin insufficiency mutations, are the most seen genetic disorders in VTE. Also, PAI-1 gene mutations that affect the fibrinolytic system and reduce fibrinolysis are risk factors for VTE. ${ }^{[4]}$ In our case, PAI SERPINE 1 homozygous 4G/4G, MTHFR homozygous 1298 CC and Factor II prothrombin 20210GA heterozygous mutations were detected. Prothrombin is produced by the liver and converted to thrombin by activated Factor X. Prothrombin 20210GA mutation firstly described by Poort et al. ${ }^{[5]}$ in 1996. In prothrombin 20210GA mutation, the Adenine nucleoid is replaced by Guanine, resulting in an increase of about $133 \%$ at the prothrombin level. While the prevalence of this mutation in the general popula- 
tion is approximately $1-4 \%$, it can be detected $2.7-17 \%$ of the VTE cases. When combined with Factor V Leiden mutation and intake of oral contraceptives, the risk of VTE is increased 17 times and seven times, respectively. ${ }^{[6]}$ MTHFR is a key enzyme in homocysteine metabolism that forms activated folate, which is essential for remethylation of homocysteine to methionine by converting 5,10-methylenetetrahydrofolate to 5-methyltetrahydrofolate. C677t and A1298C are the most common polymorphism. While Alanine was replaced by Valine at codon 222 in C677T polymorphism, in A1298C polymorphism, Alanine was replaced by Glutamine in codon 429. As a result of enzyme dysfunction, plasma homocysteine levels increased. Increased plasma homocysteine levels cause endothelial dysfunction, inhibition of fibrinolysis and platelet activation and all of them increase the VTE risk. Among the VTE cases, the incidence of C677T and A1298C are 10-25.6\% and $35-44 \%$, respectively. ${ }^{[7,8]}$ However, in our case, the homocysteine level is at normal range.

Plasminogen activator inhibitors (PAI) are responsible for primary inhibition of plasminogen activators, such as tissue plasminogen activator and urokinase-type plasmin activator. $4 \mathrm{G} / 4 \mathrm{G}, 4 \mathrm{G} / 5 \mathrm{G}$ and $5 \mathrm{G} / 5 \mathrm{G}$ polymorphisms are the most common PAI-1 gene mutations. Despite the increased PAI-1 and triglyceride levels, the association between PAI-1 polymorphism and VTE is controversial, but accompanying other thrombophilic genetic factors, such as Factor V Leiden mutation, there is an increased risk for VTE. ${ }^{[9-12]}$

Mesenteric and portal venous thrombi can also be seen among individuals with thrombophilic genetic disorders. Especially, the risk increased in young patients with more than one polymorphism. In our case, the patient does not have Factor V Leiden mutation; however, he has three genetic anomalies (PAI SERPINE 1 homozygous 4G/4G, MTHFR homozygous 1298 CC and Factor II prothrombin 20210GA heterozygous mutations). Because of the recurrence risk, for these patients, lifetime oral warfarin treatment and close screening of INR value (should be aimed INR within 2-3) are recommended. ${ }^{[13,14]}$

\section{Conclusion}

In conclusion, although MVTE is seen in the geriatric population mostly, occasionally, it can be seen in young individuals. In these cases, genetic screening must be considered because genetic disorders are the main etiological factors. High-risk patients with genetic disorders must be closely monitored, and life-long anticoagulation prophylaxis should be provided.

\section{Disclosures}

Informed consent: Written informed consent was obtained from the patient for the publication of the case report.

Peer-review: Externally peer-reviewed.

Conflict of Interest: None declared.

Authorship Contributions: Concept - S.O.,Ö.F.B., A.C.S.; Supervision - A.C.S., P.B., S.O.; Materials - P.B., S.O.; Data collection \&/or processing - S.O., P.B., A.C.S., Ö.F.B.; Analysis and/ or interpretation - S.O., A.C.S.; Writing - S.O., Ö.F.B.; Critical review - P.B., S.O.

\section{References}

1. Rhee RY, Gloviczki P. Mesenteric venous thrombosis. Surg Clin North Am 1997;77:327-38. [CrossRef]

2. Kumar S, Sarr MG, Kamath PS. Mesenteric venous thrombosis. N Engl J Med 2001;345:1683-8. [CrossRef]

3. Kreidy R, Salameh P, Waked M. Lower extremity venous thrombosis in patients younger than 50 years of age. Vasc Health Risk Manag 2012;8:161-7. [CrossRef]

4. Hotoleanu C. Genetic Risk Factors in Venous Thromboembolism. Islam S, editor. Thrombosis and Embolism: from Research to Clinical Practice. 1st ed. Springer; 2016.p.253-72.

5. Poort SR, Rosendaal FR, Reitsma PH, Bertina RM. A common genetic variation in the 39-untranslated region of the prothrombin gene is associated with elevated plasma prothrombin levels and an increase in venous thrombosis. Blood 1996;88:3698-703.

6. Jadaon MM. Epidemiology of Prothrombin G20210A Mutation in the Mediterranean Region. Mediterr J Hematol Infect Dis 2011;3:e2011054. [CrossRef]

7. Hotoleanu C, Trifa A, Popp R, Fodor D. The importance of homozygous polymorphisms of methylenetetrahydrofolate reductase gene in Romanian patients with idiopathic venous thromboembolism. Balkan Med J 2013;30:197-203. [CrossRef]

8. Fay WP. Homocysteine and thrombosis: guilt by association? Blood 2012;119:2977-8. [CrossRef]

9. Francis CW. Plasminogen activator inhibitor-1 levels and polymorphisms. Arch Pathol Lab Med 2002;126:1401-4.

10. Panahloo A, Mohamed-Ali V, Lane A, Green F, Humphries SE, Yudkin JS. Determinants of plasminogen activator inhibitor 1 activity in treated NIDDM and its relation to a polymorphism in the plasminogen activator inhibitor 1 gene. Diabetes 1995;44:37-42. [CrossRef]

11. Akar N, Yilmaz E, Akar E, Avcu F, Yalçin A, Cin S. Effect of plasminogen activator inhibitor-1 4G/5G polymorphism in Turkish deep vein thrombotic patients with and without FV1691 G-A. Thromb Res 2000;97:227-30. [CrossRef]

12. Seguí R, Estellés A, Mira Y, España F, Villa P, Falcó C, et al. PAI-1 promoter $4 \mathrm{G} / 5 \mathrm{G}$ genotype as an additional risk factor for venous thrombosis in subjects with genetic thrombophilic defects. Br J Haematol 2000;111:122-8. [CrossRef]

13. Karmacharya P, Aryal MR, Donato A. Mesenteric vein thrombosis in a patient heterozygous for factor V Leiden and G20210A prothrombin genotypes. World J Gastroenterol 2013;19:7813-5.

14. Yirmibeşoğlu M, Vitoja S, Çalık E, Terzi C. Protrombin 20210 G/A ve MTHFR C677T mutasyonları nedeniyle süperior mezenterik ven trombozu: Olgu sunumu. Turk J Surg 2011;27:111-4. 